\title{
РОЗУМІННЯ ПРИКЛАДНОГО ЗНАЧЕННЯ ДИСЦИПЛІНИ “ГІСТОЛОГІЯ, ЦИТОЛОГІЯ, ЕМБРІОЛОГІЯ" ЯК ЗАПОРУКА ФОРМУВАННЯ КЛІНІЧНОГО МИСЛЕННЯ МАЙБУТНІХ ФАХІВЦІВ
}

\author{
ВДНЗ Украӥни “Украӥнська медична стоматологічна академія” (м. Полтава), \\ ДВНЗ “Тернопільський державний медичний університет \\ імені І. Я. Горбачевського МОЗ України”
}

\section{UNDERSTANDING THE APPLIED VALUE OF THE DISCIPLINE "HISTOLOGY, CYTOLOGY, EMBRYOLOGY" AS THE KEY TO THE FORMATION OF CLINICAL THINKING OF FUTURE PROFESSIONALS

\author{
H.A. Yeroshenko, N. V. Hasyuk \\ HSEI of Ukraine "Ukrainian Medical Stomatological Academy" (Poltava) \\ SHEI "Ternopil State Medical University by I. Ya. Horbachevsky of MPH of Ukraine"
}

\begin{abstract}
Наявність клінічного мислення є невід'ємною складовою свідомості студента-медика. Особливо гостро це питання, як і питання якості освіти, стоїть відносно студентів-іноземців англомовної форми навчання. Враховуючи той факт, що поряд із знаннями гістологічної термінології фігурує питання саме лінгвістичних аспектів медичної термінології, яка $\epsilon$ бар'єром на шляху отримання якісних знань. Запропонований авторами креативний підхід до проведення практичних занять 3 предмета "Гістологія, цитологія, ембріологія" зі студентами англомовної форми навчання забезпечує формування клінічного мислення і потребує висловлення власної думки в колі студентів під час занять та співпраці із викладачем.

The presence of clinical thinking is an integral part of the consciousness of the student-medic. Especially sharply this question and the issue of quality of education, stands against foreign students in English learning. Given the fact that along with knowledge histological terminology appears a question of the linguistic aspects of medical terminology, which is a barrier on the way of obtaining high-quality knowledge. Authors ' creative approach to conducting practical lessons on the subject of "Histology, cytology, embryology" with students of English form of teaching leads to the formation of clinical thinking and requires expressing their views in a circle of students during classes and cooperation with the teacher.
\end{abstract}

Ветуп. Перехід до міжнародних стандартів вищої школи потребує удосконалення підходів до виховання та навчання майбутніх фахівців [1].

Посилення тенденцій глобалізації, які поширюються в усьому світі, змінили статус і функції іноземної мови в медичній освіті. Мова стала інструментом, що дозволяє студенту-медику краще орієнтуватися у навколишньому середовищі; вона допомагає отримати нові та вдосконалювати існуючі знання, використовуючи при цьому весь арсенал лінгвістичних надбань медичної термінології [3].

Гістологія, цитологія та ембріологія є теоретичною основою практичної медицини, завдяки якій студентмедик пізнає загальні закономірності структурної організації здорового організму перед вивченням клінічних дисциплін. Без глибокого знання будови клітин, тканин, органів неможливо розкриття законо-

(C) Г. А. Срошенко, Н. В. Гасюк мірностей порушення їх функцій, пошук механізмів їх відновлення, попередження хвороб та їх лікування на клінічних кафедрах.

Серед розмаїття форм комунікації медична термінологія займає виключно важливе місце у сучасній освіті. Писемна форма комунікації медичної англомовної освіти дозволяє студентам розширити арсенал літератури та включити до його переліку наукових та професійних досягнень сучасності $[2,5,6]$.

Успішна професійна підготовка майбутнього лікаря значним чином потребує адекватних та ефективних методів, особливо коли це стосується студентів 3 англомовною формою навчання [7].

Резервом для поліпшення якості підготовки лікарів є організація навчального процесу на основі засад Болонського процесу, орієнтована на кінцевий результат - підготовку фахівців, що відповідають вимогам медичної науки й охорони здоров'я [4]. 
Метою роботи було визначити основні засоби формування креативного мислення студентів англомовної форми навчання при вивченні дисципліни "Гістологія, цитологія, ембріологія".

Основна частина. За останні роки докорінно змінилося відношення до якості медичної освіти в цілому, а до англомовної зокрема. Слово “креативність" є латинського походження і означає "creator" - творець. Термін "креативність" запозичений з американських наукових досліджень 1957 року. Під креативністю ми розуміємо дивергентне мислення, здібність створювати щось нове.

Аналіз помилок на різних етапах теоретичної підготовки майбутніх фахівців дає можливість стверджувати, що успішний навчальний процес на клінічних кафедрах забезпечується високим теоретичним рівнем підготовки на морфологічних дисциплінах. При такому підході головна увага фокусується на кінцевому результаті обстеження пацієнта, тобто на встановленні кінцевого діагнозу, а не на тому, які конкретні дії має застосувати студент на етапі проведення суб'єктивних та об'єктивних досліджень, показаннях до призначення додаткових методів дослідження, вмінні аналізувати та синтезувати отримані дані для досягнення конкретного результату.

Аналіз недоліків сучасної медичної освіти іноземних студентів англомовної форми навчання змушує викладачів шукати шляхи поліпшення освіти та оптимізації отримання знань студентами з використанням креативного підходу до проведення практичних занять. Застосування даної методики сприяє засвоєнню матеріалу із застосуванням аналітичних операцій на етапі засвоєння матеріалу, шляхом моделювання віртуальної клінічної ситуації, що дає можливість демонстрації практичного значення матеріалу, що вивчається на занятті. Наприклад, при вивченні теми "Тканини внутрішнього середовища. Кров. Гемограма. Лейкоцитарна формула" кінцевим результатом повинно бути розуміння студентами не тільки будови і функціонального значення формених елементів крові, але й вміння інтерпретувати результати гемограми та лейкоцитарної формули.

Порядок реалізації запропонованої методики за умов 2-годинного практичного заняття забезпечується обов'язковою наявністю вступної бесіди (5-10 хвилин). Викладач знайомить студентів із темою заняття з метою його проведення та завданнями, які забезпечать досягнення мети. Чітко окреслюється проблема, яка буде складати зміст методики, що реалізується. Особливий акцент вважаємо за потрібне робити на аспектах прикладного значення теми, що вивчається. Яскравим прикладом на цьому етапі може бути аналіз помилок у зв'язку з відсутністю розуміння та недооцінки ролі лабораторних показників, а саме кількісного та якісного співвідношення формених елементів крові при різних патологічних станах організму.

На першому етапі запропонованої нами методикиетапі критики кожному студенту протягом 15-20 хвилин потрібно зафіксувати практичне значення тематики, що вивчається. Прикладом цього можуть бути основні зміни кількості і співвідношення клітин у гемограмі ілейкоцитарній формулі при анеміях, травмах, запальних процесах різної етіології, алергічних реакціях. Особливу увагу звернути на вікові особливості гемограми у людини від народження до похилого віку. По закінченню часу кожному із студентів-учасників пропонується навести результати своєї аналітичної роботи, бажано б із коротким коментарієм.

Після відповіді кожного із студентів викладач закінчує етап критики узагальнюючим коментарієм стосовно клінічного значення теми, і створює із числа студентів аналітичні групи, кожна 3 яких отримує аналіз крові віртуального пацієнта та протягом 1520 хвилин його вивчає і обговорює.

На другому етапі протягом 15-20 хвилин кожна група виступає із результатами обговорення, наводить показники, які не відповідають нормі, з урахуванням віку пацієнта. Робить припущення стосовно можливих порушень в організмі віртуального пацієнта або їх відсутності. Наприклад, наявність рівного співвідношення лімфоцитів і гранулоцитів у лейкоцитарній формулі дитини віком 4 роки.

Для оформлення розробленої моделі віртуальної програми та усвідомлення практичного значення у кожній з груп мають бути підготовані проекти ідеальних моделей, при цьому кожна з цих груп публічно представляє та захищає свою модель прикладного значення.

По ходу захисту запропонованого варіанта проводиться обговорення запропонованих моделей та заслуховуються з цього приводу думки кожного із членів команд.

Закінчується цей етап коментуванням викладача, який користуючись власним досвідом наводить дані про ідеальне вирішення завдання. Відмітимо, що при наведенні аналізу гемограм викладач може задати деякий алгоритм або приблизну структуру моделі. Наприклад, навіщо на клінічних кафедрах при моделюванні взаємовідношень “лікар-пацієнт” при інтерпретації загального аналізу крові будуть необхідні базові знання з гістології. 
На третьому етапі - “реальних дій” (15-20 хвилин) є можливість конкретної дії в рішенні обговорюваної проблеми. Даний етап має велике значення саме на клінічних кафедрах, оскільки, на нашу думку, він передбачає прийом тематичних пацієнтів. Після встановлення віртуального діагнозу відбувається детальне обговорення гематологічних показників та інтерпретація кожного відносно вікової та статевої норми. Закінчується цей етап коментуванням викладача, яке має включати конкретні рекомендації та детальний аналіз гемограми стосовно кожної клітинної фракції.

На четвертому етапі - рефлексивному (15-20 хвилин), в “рефлексивному колі" учасникам дається можливість:

- зафіксувати кожний етап віртуального діагностичного процесу та критично оцінити його;

- визначити причини припущеної помилки;

- дати самооцінку результативності взаємодії “студент-викладач" з метою свого подальшого професійного розвитку.

Викладач завершує аналіз, а також підводить підсумки реалізації запропонованої методики. При цьому важливою, на нашу думку, є детальна характеристика кожного етапу навчання з особливим акцентом на помилки, які допущені студентами.

Підводячи підсумки застосованої креативної методики, можемо стверджувати, що розвиток клінічного мислення та професійної компетенції студентів-

\section{Література}

1. Althach P. The internalization of higher education: motivations and realities / P. Althach, J. Knight // Journal of Studies in International Education. - 2007. - Vol. 11, № 3/4.P. 290-305.

2. Безрукова В. С. Мобильность системы образования / В. С. Безрукова. -Екатеринбург, 1997. - 194 с.

3. Зимняя И. А. Психологические аспекты обучения говорения на иностранном языке / И. А. Зимняя. - М. : Просвещение, 1995. -234 с.

4. Особливості викладання теоретичних дисциплін студентам факультету підготовки іноземних громадян у вищих медичних навчальних закладах / Т. В. Князевич-Чорна, іноземців може забезпечуватися, на наш погляд, трьома складовими. Перша складова - теоретична, пов'язана із знанням фундаментальних дисциплін особливостей гістологічної та анатомічної будови тканин у нормі, аспектів фізіології, суті перебігу патологічних процесів, що виникають в організмі. Теоретичні знання дадуть можливість студентам на старших курсах скласти схему лікування із урахуванням принципів індивідуалізованості, поєднаності, диференційованості. Друга складова - практична, усвідомлення якої повинно формуватися вже у студентівпершокурсників. Третя складова - аналітична - розвиває вміння аналізувати, синтезувати та зіставляти отримані результати основних клінічних методів із результатами додаткових методів обстеження, що сприяє формуванню особистості всебічно розвиненого фахівця, який володіє арсеналом гемоцитологічних знань, біохімічного аналізу крові, вмінням трактувати результати мікробіологічного та цитологічного результатів дослідження.

Висновок. Застосування креативного підходу до проведення практичних занять на кафедрі гістології, цитології та ембріології зі студентами, які навчаються англійською мовою, сприяє формуванню висококваліфікованих спеціалістів вже на перших курсах навчання в обраній професійній ніші, сприяючи розвитку теоретичних знань, залучаючи до навчання як види мовленнєвої діяльності викладача, так і прикладні особисті напрацювання.

М. І. Грищук, О. Г. Попадинець [та ін.] // Медична освіта. 2011. -№ 4. - С. 17-19.

5. Ніколаєва С. Ю. Ступенева система освіти в Україні та система навчання іноземних мов / С. Ю. Ніколаєва, О. П. Тетращук, І. Д. Бражник. - К. : Ленвіт, 1996. C. 122-136.

6. Обучаем иначе. Стратегия активного обучения / Е. К. Григальчик, Д. И. Губаревич, И. И. Губаревич, С. В. Петрусёв. -Мн. : БИП-С, 2003.- 182 c.

7. Степко М. Р. Українська освіта в Болонському процесі: досвід, перспективи / М. Р. Степко // Директор школи, ліцею, гімназії. 2006 . - № 6. - С. 107-111. 